\title{
Diversity of ticks biting humans in Aydın province of Turkey
}

\author{
Serkan BAKIRCI, Nuran AYSUL, Hasan EREN, Ahmet Hakan ÜNLÜ, Tulin KARAGENÇ
}

Adnan Menderes University, Faculty of Veterinary Medicine, Department of Parasitology, Işıklı Mevki, Aydın, Turkey.

Summary: A total of 3655 samples collected from people applied to the hospitals with a complaint of tick bite between February 2007 and November 2008 in Aydin Province (Turkey) were examined in the present study. The samples were evaluated in respect to species, sex, development periods, host speciality and seasonal distribution. Of 3655 samples, 14,49\% (n=530) were not ticks. On the other hand, $12,33 \%(\mathrm{n}=462)$ of examined samples were comminuted and therefore could not be identified on the basis of genus or species. Results indicated that 9 out of 2664 ticks $(0,3 \%)$ were Argasidae, while 2655 of them $(99,7 \%)$ were Ixodidae. Evaluation of the developmental periods of ticks and the distribution of tick species indicated that the majority of the ticks were the nymph of Hyalomma spp. ( $\mathrm{n}=1718)$, constituting $64,71 \%$ of all samples. Results obtained from the present study further indicated Hyalomma marginatum $(\mathrm{n}=409,15,40 \%)$ as the most common tick species among adult ticks within the Hyalomma spp.

Keywords: Aydın, human, tick bites, Turkey.

\section{Aydın ilinde insanları tutan kene türlerinin çeşitliliğ̣i}

Özet: Bu çalışma da Aydın ilinde (Türkiye) Şubat 2007 ile Kasım 2008 tarihleri arasında, kene tutunma şikayeti ile hastanelere başvuran insanlardan toplanan 3655 örnek incelenmiştir. Keneler tür, cinsiyet, gelişme dönemleri, konak özellikleri ve mevsimsel dağılımları bakımından irdelenmiştir. İncelen örneklerin \%14,49'unda $(\mathrm{n}=530)$ keneye rastlanmamış, ayrıca örneklerin \% 12,33'ü de $(\mathrm{n}=462)$ tür veya soy bazında tanımlanamayacak kadar parçalanmış olduğundan teşhisleri yapılamamıştır. Teşhisi yapılan 2664 kenenin 9'unun (\% 0,3) Argasidae, 2655'inin ise (\%99,7) Ixodidae ailesine bağlı olduğu anlaşılmıştır. Kenelerin gelişim dönemi ve tür dağılımlarını belirlemek üzere yapılan değerlendirmelerde sayısal üstünlügün Hyalomma spp. nimflerine (n=1718) ait olduğu ve toplam örneklerin \%64,71 ini oluşturdukları tespit edilmiştir. Erişkin kenelerin tür bazında yapılan incelemelerinde ise en fazla Hyalomma marginatum $(\mathrm{n}=409, \% 15,40)$ türüne rastlanmıştır.

Anahtar sözcükler: Aydın, insan, kene tutunması, Türkiye.

\section{Introduction}

Ticks are obligatory blood-sucking arthropods, especially observed in tropical and subtropical belts (25). Tick species are important for veterinary medicine and human health. In addition to the direct effects of tick species, they are vectors for many infectious agents. Vector ticks transfer some of infectious agents to next generations, making the control of these infections rather more diffucult $(35,38)$. There are 896 species of ticks in 3 families, viz. Nuttalliellidae, Argasidae and Ixodidae. While the Nuttalliellidae is monotypic, containing the single entity Nuttalliella namaqua, families Argasidae and Ixodidae consist of 193 and 702 species, respectively $(7,17)$. To date, a total of 46 tick species have been identified throughout Turkey, which belong to two ticks families, viz. Argasidae and Ixodidae (9). Among these, the ticks of in the family Ixodidae and Argasidae that have been in various parts of Turkey are as follows: Ixodes ricinus, I. frontalis, I. gibbosus, I. hexagonus, Haemaphysalis parva, Hae. punctata, Hae. sulcata, Hae. concinna, Hae. erinacei, Hyalomma aegyptium, $H$. anatolicum, $H$. excavatum, $H$. marginatum, $H$. scupense, H. dromedarii, H. impeltatum, H. rufipes, H. turanicum, Dermacentor marginatus, D. niveus, D. reticulatus, Rhipicephalus (Boophilus) annulatus, Rhipicephalus bursa, $R$. sanguineus, $R$. turanicus, Argas persicus, A. reflexus, A. vespertilionis, Ornithodorus lahorensis, $O$. erraticus, $O$. coniceps, $O$. tholozani and Otobius megnini $(3,6,8,9,24)$.

Ticks are the most important vectors within arthropods after mosquitoes which transmit infections to both humans and animals $(12,36)$. Approximately, 10\% of all known tick species play a role in the circle of pathogen-tick-vertebrata $(19,26)$. Pathogens including protozoa, viruses, bacteria, ricketsia and helminth species are transfered by ticks $(24,34)$. Eventhough ticks have host-selectivity, they are known to be able to use various hosts to feed (34). Although, 222 of tick species suck blood from humans, only 33 of them frequently prefer humans as a host and among these only 28 play a direct 
role in transmission of disease agents (14). Therefore, ticks which exist especially in endemic regions are important for public health (29). Population of ticks and infestation rate of the hosts differ in a given region depending on seasonal fluctuations, land structure, vegetation and climatic change in tick population (4). Therefore, all these considerations should be taken into account to take preventive measures against tick species.

The present study was carried out to examine the seasonal distribution of tick species biting on humans and environmental factors affecting tick-host interactions in Aydınprovince.

\section{Material and Method}

The region of study: Aydin is a city that lies in the Big Menderes basin located at the West Anatolia (37 ${ }^{\circ}-44^{\prime}$ and $38^{\circ}-08^{\prime}$ north latitudes $-27^{\circ}-23^{\prime}$ and $28^{\circ}-52^{\prime}$ east longitudes), comprising $8007 \mathrm{~km}^{2}$ area. Altitude of Aydın is about $40 \mathrm{~m}$. Population of the province is about 1.007.373 in 2013. Coast of Aegean Sea defines the province's west borders. The climate is of Mediterranean type and the flora is mostly scrub and woody. Most of the rain falls ocur in winter, with only little or no rain during the summer season. It rarely snows and only at high altitudes of the region. Average temperature is $17-$ $18{ }^{\circ} \mathrm{C}$ and the amout of rainfall is between $580-1000 \mathrm{~m}^{3}$ in a year. Aydın has a big important potential of agriculture where River of Big Menderes hydrates the plains. Majority of the population $(85 \%)$ earns their livings through both livestock production and agriculture. Mainly intensive livestock breeding is performed in Aydın Province. Besides, animal production performed as small family business in the countryside depends mainly on the use of rangelands.

Ticks and Analysis of Data: Tick samples were collected from people applied to the hospitals with a complaint of tick bite between February 2007 and November 2008. Adult ticks were identified on the genus and species levels using relevant litterateurs $(18,24)$. Stage of larvae and nymph were identified at the genus level. As some samples were fragmented before sampling and therefore could not be classified on both genus and species levels. Data in relation to sex, species and development periods and age of ticks and, location and bitten body parts of hosts were saved. Bitten body parts of hosts were divided into 4 groups as head, extremity, body and genital region. Age of hosts were divided into 8 groups as $0-6,7-12,13-18,19-25,26-40,41-55,56-65$ and over 65 . Data as for the location of hosts bitten by ticks were divided into 2 groups as rural and urban. When some data of samples which were sent from hospitals were missing, all the parameters were grouped as unknown.

\section{Results}

Tick Species: A total of 3655 samples taken from human cases with a complain of tick-bite were accepted to our laboratory through various hospitals. Of these, $8,94 \%(n=327)$ of samples that came with sample boxes from hospitals were empty, 5,55 \% $(\mathrm{n}=203)$ were not ticks but flea, spider, etc and $12,33 \%(\mathrm{n}=462)$ were fragmented badly thus could not be identified on the level of genus or species. It was found that 9 of 2664 identified ticks were $(0,3 \%)$ Argasidae, all were Argas percicus, and 2655 of them were (99,7\%) Ixodidae. Ixodid ticks were futher examined with respect to species, the location of the host and the season. Results indicated that Hyalomma spp. nymphs constituted the majority of ticks $(64,71 \%, \mathrm{n}=1718)$. The distribution of Ixodid ticks at the genus level were as follows; 86,97\% Hyalomma spp ( $\mathrm{n}=550$ adult, $\mathrm{n}=1718$ nymph and $\mathrm{n}=41$ larvae), $8,36 \%$ Rhipicephalus spp $(\mathrm{n}=186$ adult, $\mathrm{n}=33$ nymph and $\mathrm{n}=3$ larvae), $2,45 \%$ Dermacentor marginatus $(\mathrm{n}=65$ adult), 1,99 \% Ixodes $\operatorname{spp}(\mathrm{n}=38$ adult and $\mathrm{n}=15$ nymph), $0,23 \%$ Haemaphysalis spp ( $\mathrm{n}=4$ adult and $\mathrm{n}=2$ nymph) (Table 1). Examination of adult ticks on the species level indicated that H.marginatum $(\mathrm{n}=409,15,40 \%)$ was the most common species, followed by $R$. turanicus, $H$. excavatum, D. marginatus, $H$. aegyptium, I. ricinus, $R$. sanguineus, $H$. scupense, $R$. bursa, $H$. anatolicum, Haemaphysalis parva, $R$. annulatus and H. rufipes (Table 5).

Table 1. The distribution of genus and life stages of ticks. Tablo 1. Kenelerin cins ve gelişme dönemlerine göre dağılımı.

\begin{tabular}{lcccccc}
\hline Genera & $\mathrm{F}$ & $\mathrm{M}$ & $\mathrm{L}$ & $\mathrm{N}$ & Total & Preval (\%) \\
\hline Hyalomma spp. & 206 & 344 & 41 & 1,718 & 2,309 & 86,97 \\
Rhipicephalus spp. & 95 & 91 & 3 & 33 & 222 & 8,36 \\
Dermacentor spp. & 34 & 31 & - & - & 65 & 2,45 \\
Ixodes spp. & 36 & 2 & - & 15 & 53 & 1,99 \\
Haemaphysalis spp. & 3 & 1 & - & 2 & 6 & 0,23 \\
Total & 374 & 469 & 44 & 1,768 & 2,655 & 100 \\
\hline
\end{tabular}

$F$ Female, $M$ Male, $L$ Larvae, $N$ Nymph

Tick-Host relation: It was found that body and extremities were mostly chosen by Hyalomma spp and Rhipicephalus spp. On the other hand, Dermacentor spp mainly preferred the head and extremities for feeding (Table 2). Data gathered as for the age distribution of potential hosts attacked by each tick species indicated that $0-6$ age kids were bitten mainly by Hyalomma spp nymphs, wheras 26-55 middle age adults were bitten mainly by $H$. marginatum. As for the other tick species examined in the present study, the age of the host did not appear to be important (Tablo 3). The present study indicates that while1574 of $2655(59,28 \%)$ tick biting cases occurred in rural regions, $1081(40,72 \%)$ of them occurred in urban regions. A list of tick biting cases that occured in rural and urban regions are given in Table for each tick species (Table 4). 
Table 2. Distribution of ticks based on the bite sites on the humans.

Tablo 2. İnsanlarda tutunma bölgelerine göre kenelerin dağılımı.

\begin{tabular}{lcccccc}
\hline Genera & \multicolumn{3}{c}{ Attachment sites of ticks } & \multicolumn{2}{c}{ Total } \\
\cline { 2 - 5 } & Head & Extremity & Body & Genital region & Unknown \\
\hline Hyalomma spp (adults) & 61 & 219 & 106 & 28 & 136 & 550 \\
Hyalomma spp (nymph, larva) & 315 & 586 & 364 & 209 & 285 & 1,759 \\
Rhipicephalus spp (adults) & 65 & 59 & 28 & 7 & 27 & 186 \\
Rhipicephalus spp (nymph, larva) & 12 & 8 & 5 & 3 & 5 & 36 \\
Dermacentor marginatus & 22 & 18 & 11 & 5 & 9 & 65 \\
Ixodes ricinus & 18 & 13 & 5 & - & 1 & 38 \\
Ixodes spp (nymph) & 6 & 5 & 3 & - & 1 & 15 \\
Haemaphysalis parva & 2 & - & 1 & - & 1 & 4 \\
Haemaphysalis spp (nymph) & 1 & - & - & 253 & 469 & 2,655 \\
Total & 502 & 908 & 523 & & & 1 \\
\hline
\end{tabular}

Table 3. Distribution of ticks based on the ages of the humans.

Tablo 3. İnsanların yaş gruplarına dayalı kenelerin dağılımı.

\begin{tabular}{lccccccccccc}
\hline Genera & \multicolumn{9}{c}{ Age groups } & \multicolumn{1}{c}{ Total } \\
\cline { 2 - 10 } & $0-6$ & $7-12$ & $13-18$ & $19-25$ & $26-40$ & $41-55$ & $56-65$ & 65 -over & Unknown \\
\hline Hyalomma spp (adults) & 56 & 41 & 30 & 43 & 120 & 140 & 62 & 44 & 14 & 550 \\
Hyalomma spp (nymph, larvae) & 458 & 219 & 92 & 107 & 258 & 261 & 157 & 170 & 37 & 1,759 \\
Rhipicephalus spp (adults) & 40 & 34 & 12 & 16 & 36 & 24 & 12 & 8 & 4 & 186 \\
Rhipicephalus spp (nymph, larvae) & 19 & 3 & 1 & 1 & 4 & 4 & 1 & 3 & - & 36 \\
Dermacentor marginatus & 10 & 7 & - & 9 & 16 & 10 & 4 & 6 & 3 & 65 \\
Ixodes ricinus & 4 & 8 & 1 & 5 & 9 & 4 & 5 & 2 & - & 38 \\
Ixodes spp (nymph) & 3 & 3 & 2 & 1 & 2 & 1 & 3 & - & - & 15 \\
Haemaphysalis parva & 1 & - & - & - & 1 & - & - & 2 & - & 4 \\
Haemaphysalis spp (nymph) & - & 1 & - & - & - & - & 1 & - & - & 2 \\
Total & 591 & 316 & 138 & 182 & 446 & 444 & 245 & 235 & 58 & 2,655 \\
\hline
\end{tabular}

Table 4 . The distribution of tick bites by species, type of locality.

Tablo 4. Kene türlerinin tutunma yeri tipine göre dağ 11 เmı.

\begin{tabular}{lcc}
\hline & \multicolumn{2}{c}{ The number of ticks } \\
\cline { 2 - 3 } Tick species & \multicolumn{2}{c}{ Place of tick contact } \\
\cline { 2 - 3 } & Rural & Urban \\
\hline H.aegyptium & 29 & 18 \\
H.anatolicum & 4 & 2 \\
H.scupense & 12 & 5 \\
H.excavatum & 28 & 42 \\
H.marginatum & 295 & 114 \\
H.rufipes & 1 & 0 \\
H.nymph & 986 & 734 \\
H.larva & 24 & 17 \\
R(B)annulatus & 0 & 1 \\
R.bursa & 9 & 4 \\
R.sanguineus & 17 & 8 \\
R.turanicus & 90 & 55 \\
R.nymph & 19 & 14 \\
R.larva & 2 & 1 \\
Dermacentor marginatus & 30 & 35 \\
Ixodes ricinus & 15 & 23 \\
I.nymph & 9 & 6 \\
Haemaphysalis parva & 3 & 1 \\
Hae.nymph & 1 & 1 \\
Total & 1574 & 1081 \\
& $(\% 59,28)$ & $(\% 40,72)$ \\
\hline
\end{tabular}


Table 5. The seasonal distribution of tick species.

Tablo 5. Kene türlerinin mevsimsel dağılımı.

\begin{tabular}{|c|c|c|c|c|c|c|c|c|c|c|c|c|c|c|}
\hline \multirow{2}{*}{$\begin{array}{l}\text { Genera and } \\
\text { Species }\end{array}$} & \multicolumn{14}{|c|}{ Months } \\
\hline & $\begin{array}{l}\text { January } \\
\end{array}$ & February & March & April & May & June & July & August & September & October & November & December & Total & $\begin{array}{c}\text { Preval } \\
(\%)\end{array}$ \\
\hline \multicolumn{15}{|l|}{ Hyalomma spp } \\
\hline H.aegyptium & - & - & 1 & 2 & 3 & 19 & 11 & 6 & 3 & 2 & - & - & 47 & 1,77 \\
\hline H.anatolicum & - & - & - & - & - & 4 & 2 & - & - & - & - & - & 6 & 0,23 \\
\hline H.scupense & - & - & - & - & - & 5 & 8 & 3 & - & - & 1 & - & 17 & 0,64 \\
\hline H.excavatum & - & - & - & 2 & 1 & 16 & 25 & 13 & 10 & 2 & - & 1 & 70 & 2,64 \\
\hline H.marginatum & - & 1 & 4 & 17 & 25 & 126 & 137 & 65 & 24 & 7 & 3 & - & 409 & 15,40 \\
\hline H.rufipes & - & - & - & - & - & - & 1 & - & - & - & - & - & 1 & 0,04 \\
\hline H.nymph & - & 2 & 2 & 6 & 10 & 101 & 260 & 489 & 625 & 218 & 5 & - & 1,718 & 64,71 \\
\hline H.larva & - & - & - & - & 1 & 3 & 10 & 13 & 12 & 2 & - & - & 41 & 1,54 \\
\hline \multicolumn{15}{|c|}{ Rhipicephalus spp. } \\
\hline$R(B)$ annulatus & - & - & - & - & - & - & 1 & - & - & - & - & - & 1 & 0,04 \\
\hline R.bursa & - & - & - & - & - & 7 & 6 & 1 & - & - & - & - & 14 & 0,53 \\
\hline R.sanguineus & - & - & 1 & 5 & 2 & 7 & 2 & 5 & 1 & 3 & - & - & 26 & 0,98 \\
\hline R.turanicus & - & - & 8 & 53 & 23 & 33 & 13 & 9 & 2 & 2 & 2 & - & 145 & 5,46 \\
\hline R.nymph & - & - & - & - & - & 3 & 19 & 4 & 7 & - & - & - & 33 & 1,24 \\
\hline R.larva & - & - & - & - & - & - & 1 & 2 & - & - & - & - & 3 & 0,11 \\
\hline $\begin{array}{l}\text { Dermacentor } \\
\text { marginatus }\end{array}$ & - & - & 5 & 23 & 1 & - & - & 2 & 7 & 18 & 8 & 1 & 65 & 2,45 \\
\hline Ixodes ricinus & - & 1 & 11 & 18 & 8 & - & - & - & - & - & - & - & 38 & 1,43 \\
\hline I.nymph & - & - & - & 13 & - & 2 & - & - & - & - & - & - & 15 & 0,56 \\
\hline $\begin{array}{l}\text { Haemaphysalis } \\
\text { parva }\end{array}$ & - & - & - & 1 & - & 1 & - & - & - & 2 & - & - & 4 & 0,15 \\
\hline Hae.nymph & - & - & - & - & - & 1 & 1 & - & - & - & - & - & 2 & 0,08 \\
\hline Total & - & 4 & 32 & 140 & 74 & 328 & 497 & 612 & 691 & 256 & 19 & 2 & 2,655 & 100 \\
\hline
\end{tabular}

Seasonal Distribution: Evaluation of the distribution of tick bites on a montly base indicated that bites by Hyalomma spp increased in February - October with the highest numbers of bites occuring during the summer season. Dermacentor spp caused more infestation during a year except January-February and June-July, especially on autumn season, while Rhipicephalus spp caused more infestation between March and November, especially on June. On the other hand, infestations caused by Ixodes spp occurred more often between February and June (Table 5).

\section{Discussion}

Climatic conditions is one of the main determinants of disease transmission by vectors (30). Efficient control of ticks and tick-borne diseases can only be obtained through accurate data concerning (geografical and seasonal distribution of ticks) as well as epidemiologic data as for the diseases transmitted by the ticks.

Among the 46 different tick species known to exist in Turkey, 38 tick species in six genus within the Ixodidae family, viz. Haemaphysalis, Hyalomma, Dermacentor, Rhipicephalus, Ixodes are important for medical and veterinary medicine $(3,9)$. Previous studies performed on cattles demonstrated the existance of eight different tick species in three genus in Aydın province
(6). The present study further demonstrate that ticks that belong to 13 different tick species within five genus bite on humans. Although Hyalomma aegyptium, H.rufipes, Rhipicephalus bursa, Ixodes ricinus, Haemaphysalis parva species could not be determined on cattles in Aydin province, data gathered in the present study indicates that they bite on humans. Results of the present study are in agreement with other studies performed in other regions of Turkey except for $H$. rufipes $(10,11,15,16,23,39)$. Hyalomma rufipes was previously found on cattles in Manisa and Izmir provinces (5) and on horses in Bursa province (20). This species is accepted as the main vector of Crimean-Congo hemorrhagic fever in Africa (37).

While larvae and nymph forms of Hyalomma aegyptium mostly parasitize on aves, reptiles and some mammals, the adults parasitize mainly on turtles. The adult form of $H$. aegyptium are also demonstrated to parasitizes on humans (39). The present study confirms these observations and demonstrates that $H$. aegyptium does parasitize on humans.

The present study showed that the ticks biting on humans were mostly of the genus Hyalomma and that the nymph of Hyalomma spp was the most commonly encountered form in this genus. Most of the ticks show high level of host selectivity depending on the developmental period. Host selectivity is at a lower level 
at the larval and nymphal instar forms. This is especially the case for the pasture ticks (34). Previous studies performed on humans indicate that the majority of tick bites are caused by nymph form $(15,23)$. Evidence obtained in the present study is in support of these observations as for the Hyalomma spp., but not for the Rhipicephalus, Dermacentor and Ixodes spp, where bites were caused mostly by adult ticks, rather than nymphs.

Although I.ricinus could not be determined on cattles (6), the present study demonstrates the existance of these ticks on humans. There are two possible explanations for this observation. First, these species were carried by humans coming to Aydin for holiday. In support of this hypothesis, I. ricinus are mostly found on humans applied to hospitals with a complaint of tick bite in Didim and Kuşadası, two popular touristic towns located at the coastline of Aydın. Majority of people with a tick bite are in fact known to reside in different provinces of Turkey coming to Aydin only for touristic purposes. Second, I.ricinus was carried to Aydın by migratory birds. Being mainly of woodland and being at the coastline having high humidity, Kuşadası and Didim provide a suitable environment for ticks that might have arrived to the region by migratory birds.

The present study demonstrated that one biting case was caused by Rhipicephalus (B) annulatus. Considering the fact that Rhipicephalus (B) annulatus is a one-host tick parasitizing mainly cattles (34), it is most likely that this is an accidental event.

Previous studies demonstrated that ticks biting on humans are mainly adult forms of I.ricinus (39), H.marginatum (23) and H.excavatum (11). In agreement with these observations, it was found in the present study that H.marginatum was the most frequent adult tick biting on humans. H. marginatum is known as a tick species which is closely associated with animals in the wild. Larvae and nymph stages of this tick species prefer mainly small mammals (especially rabbit and hedgehog) and ground feeding birds. Micro and macro habitat of Aydın provides a good environment for this tick species. In fact, previous studies on cattles indicated this species as the most encountered species (4) in Aydin. Increasing use of woodlands by people for agriculture is most likely to be the underlying reason for the relatively high proportion of tick bites on humans by $H$. marginatum. It is known that $H$. marginatum is the main vector of Crimean-Congo viruses in Balkan States, Crimea and Caucasus (37). The disease was first detected in the Aegean region of Turkey serologically in 1980 (33), with no detected case until 2002 in the East Black Sea region. Since then, 33 cases were reported between 2006-2008 in the Aydin province (1).

It appears in the light of the data gathered in the present study that tick bites caused by nymphs are more frequent during the summer and spring seasons when people spend more time in the field. This is in agreement with previous observations (27).
The parts of the body where ticks bite differ according to the species of the tick and the development period (22). Although tick bites can be seen throughout the body from head to toe, it is generally observed on the head and neck, lower extremities and arms $(2,28)$. For example, Hyalomma spp and Rhipicephalus spp feed on the trunk and extremities (23). On the other hand, Dermacentor spp feed from extremities, wheras Haemaphysalis spp feed on the head region (23). In another study, H.aegyptium preferred to attach to the extremities, whereas H.marginatum to the trunk. As for D.marginatus, adults of this species preferred to bite the hairy skull of the victims (21). In the present study, Dermacentor spp mainly preferred the head and extremities for feeding wheras Hyalomma spp and Rhipicephalus spp.mainly preferred the trunk and extremities. Similar preference was reported previously for infestation of D.marginatus $(31,32)$.

In Aydin province, $59,45 \%$ of people live in the urban areas, wheras $40,55 \%$ of the population live in villages. It was found in the present study that the proportion of tick bites was higher in rural areas than that observed in urban areas (59,78\% vs. $40,72 \%)$ of them were seen in urban regions. This is in agreement with the generally accepted view that people working in the field such as farmers, veterinarians, health workers, soldiers and campers are under higher risk for tick bites $(2,11)$.

Activities of ticks are in a close association with the heat, moisture, rainfall, height and vegetation (16). Besides, risk of disease transmission by ticks depend on the existance and prevalence of ticks that have the ability to feed on humans as a host (39).

Taken together, the data gathered in the present study demonstrate that tick species, especially H.marginatum, R.turanicus and H.aegyptium as well as nymphs of Hyalomma spp. Can feed on humans as a host more prominently than other tick species and devolepmental stages.

\section{References}

1. Anonymous (2010): The Ministry of Health of Turkey http://kirimkongo.gov.tr/

2. Arıkan İ, Tıraş Ü, Saraçoğlu D, Taşar MA, Dallar Y (2009): Evaluation of the cases appealed as CrimeanCongo hemorrhagic fever. Ege Journal of Medicine, 48, 29-31.

3. Aydın L, Bakırcı S (2007): Geographical distribution of ticks in Turkey. Parasitology Research, 101: 163 - 166.

4. Bakırcı S (2009): Distribution of Tick Species on Cattle in the Western Anatolia. Dissertation, University of Uludag.

5. Bakırcı S, Sarali H, Aydın L, Latif A, Eren H, Karagenç T (2011): Hyalomma rufipes (Koch, 1844) infesting cattle in the West Aegean region of Turkey. Turkish Journal of Veterinary and Animal Science, 35: 359-363.

6. Bakırcı S, Sarali H, Aydın L, Eren H, Karagenç T (2012): Distribution and seasonal activity of tick species on cattle in the West Aegean region of Turkey. Experimental Applied Acarology, 56: 165-178. 
7. Barker SC, Murrell A (2004): Systematics and evolution of ticks with a list of valid genus and species names. Parasitology, 129: 15-36.

8. Bursalı A, Tekin S, Orhan M, Keskin A, Özkan M (2010): Ixodid ticks (Acari: Ixodidae) infesting humans in Tokat Province of Turkey: species diversity and seasonal activity. Journal of Vector Ecology, 35: 180-186.

9. Bursalı A, Keskin A, Tekin S (2012): A review of the ticks (Acari: Ixodidae) of Turkey: species diversity, hosts and geographical distribution. Experimental Applied Acarology, 57: 91-104.

10. Çelebi S, Aydın L, Hacımustafaoğlu M, Çelik U, Çakır D, Emir BR, Çetin M (2010): Evaluation of Children Cases Admitted for Tick Bite in Uludag University Medicine of Faculty. Journal of Pediatric Infection, 4: 133-137.

11. Değer S, Biçek K, Özdal N, Yılmaz AB, Denizhan V, Hallaç B, Sona A (2010): Distribution of Tick Species Collected from Individuals Who Applied to Health Centres due to Tick Bite in the Ercis District of Van. The Journal of The Faculty of Veterinary Medicine University of Yuzuncu Y11, 21: 95-98.

12. de la Fuente J, Estrada Pena A, Venzal JM, Kocan KM, Sonenshine DE (2008): Overview: Ticks as vectors of pathogens that cause disease in humans and animals. Frontiers in Bioscience, 13: 6938-6946.

13. Estrada Pena A, Bouattour A, Camicas JL, Walker AR (2004): Ticks of Domestic Animals in the Mediterranean Region: a Guide to Identification of Species. Published by University of Zaragoza, Spain.

14. Estrada-Pena A, Jongejan F (1999): Ticks feeding on humans: a review of records on human-biting Ixodoidea with special reference to pathogen transmission. Experimental Applied Acarology, 23: 685-715

15. Gargılı A, Kar S, Yılmazer N, Cerit Ç, Sönmez G, Şahin F, Alp HG, Vatansever Z (2010): Evoluation of ticks biting humans in Thrace province, Turkey. Journal of the Faculty of Veterinary Medicine Kafkas University, 16 (Suppl A): 141-146.

16. Gargılı A, Kar S, Yılmazer N, Ergönül Ö, Vatansever Z (2011): Different abundances of human-biting ticks in two neighboring provinces in Turkey. Journal of the Faculty of Veterinary Medicine Kafkas University, 17 (Suppl A): 93-97.

17. Guglielmone AA, Robbins RG, Apanaskevich DA, Petney TN, Estrada - Pena A, Horak IG, Shao R and Barker SC (2010): The Argasidae, Ixodidae and Nuttalliellidae (Acari: Ixodida) of the world: a list of valid species names. Zootaxa. 2528: 1 - 28.

18. Hoogstral H (1956): African Ixodoidea. I Ticks of the Sudan. U.S. Naval Medical Research Unit Cario, Egypt, No: 3 .

19. Jongejan F, Uilenberg G (2004): The global importance of ticks. Parasitology, 129 Suppl: 3-14.

20. Kar S, Güven E, Vatansever Z (2009): Marmara Bölgesindeki bir harada kene enfestasyonu ve $H$. rufipes varlığl. XVI. Ulusal Parazitoloji Kongresi, 1-7 Kasım, Adana, 254.

21. Kar S, Dervis E, Akın A, Ergonul O, Gargili A (2013): Preferences of different tick species for human hosts in Turkey. Experimental Applied Acarology, doi: 10.1007/s10493-013-9698-2.

22. Karaer Z (1983): Anakara ili ve civarinda bulunan kene türleri ile Hyalomma scupense'un (Schulze, 1919) bazı ekolojik özellikleri üzerine araştırmalar. Tübitak VII. Bilim Kongresi Tebliğleri, Ankara, 371-377.

23. Karaer Z, Güven E, Nalbantoğlu S, Kar S, Orkun Ö, Ekdal K, Kocak A, Akçay A (2011): Tics on humans in Ankara, Turkey. Experimental Applied Acarology, 54: 85-91.
24. Karaer Z, Yukarı BA and Aydin L (1997): Türkiye keneleri ve vektörlükleri. 363-434. In: Ozcel MA and Daldal N (Eds.), Parazitolojide arhropod hastalıkları vektörler. Türkiye Parazitoloji Derneği, Yayın no:13, Izmir.

25. Klompen JSH, Black WC IV, Keirans JE, Oliver JH Jr (1996): Evolution of ticks. Annual Review Entomology, 41: 141-161.

26. Labuda M, Nuttall PA (2004): Tick-borne viruses. Parasitology, 129 Suppl: 221-245.

27. Över L, İnceboz T, Yapar N, Bakırcı S, Günay T, Akısü Ç (2012): Investigation of the Cases Presenting to Dokuz Eylül University Hospital with Tick Bites. Turkish Journal of Parasitology, 36: 75-81.

28. Özkurt Z, Kiki İ, Erol S, Erdem F, Yılmaz N, Parlak M, Gündogdu M, Taşyaran MA (2006): Crimean-Congo hemorrhagic fever in Eastern Turkey: clinical features, risk factors and efficacy of ribavirin therapy. The Journal of Infection, 52, 207-215.

29. Randolph SE (2004): Evidence that climate change has caused 'emergence' of tick-borne diseases in Europe? International Journal of Medical Microbiology, 293: 5-15.

30. Randolph SE (2010): To what extent has climate change contributed to the recent epidemiology of tick-borne diseases? Veterinary Parasitology, 167: 92-94.

31. Rieg S, Schmoldt S, Theilacker C, de With K, Wölfel S, Kern WV, Dobler G (2011): Tick-borne lymphadenopathy (TIBOLA) acquired in Soutwestern Germany. BMC Infectious Diseases, 11:167.

32. Selmi M, Bertolotti L, Tomassone L, Mannelli A (2008): Rickettsia slovaca in Dermacentor marginatus and Tick-borne Lymphadenopathy, Tuscany, Italy. Emerging Infectious Diseases, 14: 817-820.

33. Serter, D (1980): Present status of arbovirus seroepidemiology in the Aegean Region of Turkey. 155-161. In: Vesenjak-Hirjan J, Porterfield JS, Arslanagic E (Eds), Arboviruses in the Mediterranean Countries. Gustav Fisher Verlag, Stuttgart.

34. Sonenshine DE (1993): Biology of ticks. Oxford University Press, New York.

35. Soulsby EJL (1986): Arachnida, helmints, arthropods and protozoa of domesticated animals. Bailliere Tindall, London 11, 456-475.

36. Sutherst RW (2004): Global change and human vulnerability to vector-borne diseases. Clinical Microbiology Rewiews, 17: 136-173.

37. Turell M (2007): Role of ticks in the transmission of Crimean-Congo Hemorrhagic Fever Virus. 143-154. In: Ergonul O, Whitehouse CA (Eds.), Crimean-Congo Hemorrhagic Fever: A Global Perspective.

38. Ullenberg G (1992): Veterinary sicnificance of ticks and tick-borne diseases. 23-35. In: Fivaz B, Petney T, Horak I (Eds), Tick vector biology. Medical and Veterinary Aspects, Springer-Verlag Berlin Heidelberg.

39. Vatansever Z, Gargılı A, Aysul NS, Sengöz G, EstradaPena A (2008): Ticks biting humans in the urban area of Istanbul. Parasitology Research, 102: 551-553.

Geliş tarihi: 30.09.2013 / Kabul tarihi: 14.01.2014

Address for correspondance:

Dr. Serkan Bakurcl

Faculty of Veterinary Medicine,

Department of Parasitology,

Adnan Menderes University,

Isıklı 09016, Aydin, Turkey

email: bakirciserkan@adu.edu.tr 